\title{
Complex Resistance to Leaf Diseases of Spring Barley in Leningrad Region
}

\author{
Lyubov M. Bondareva \\ Federal State Budget Institution \\ Leningrad research institute for \\ agricultural science «BELOGORKA» \\ Leningrad region, Gatchina district, \\ v.Belogorka, Russian Federation, \\ e-mail: lenniish@mail.ru \\ Lyudmila I. Kartasheva \\ Federal State Budget Institution \\ Leningrad research institute for \\ agricultural science «BELOGORKA» \\ Leningrad region, Gatchina district, \\ v.Belogorka, Russian Federation, \\ e-mail: lenniish@mail.ru
}

\author{
Tatiana N. Radyukevich \\ Federal State Budget Institution \\ Leningrad research institute for \\ agricultural science «BELOGORKA» \\ Leningrad region, Gatchina district, \\ v.Belogorka, Russian Federation, \\ e-mail: lenniish@mail.ru \\ Dmitry A. Danilov \\ Federal State Budget Institution \\ Leningrad research institute for \\ agricultural science «BELOGORKA» \\ Leningrad region, Gatchina district, \\ v.Belogorka, Russian Federation, \\ e-mail: stown200@mail.ru
}

\begin{abstract}
The article presents a study of the comparative characteristics of new promising lines of spring barley L1623 (nutans), L1505 (pallidum) and standards of varieties Suzdalets (nutans) and Leningrad (pallidum) on resistance to leaf diseases in various meteorological conditions of the growing season of 2012-2017. Assessment of leaf pathogens was carried out on a natural infectious background. Barley leaves were infested with powdery mildew (Blumeria graminis / DC), dark brown (Cochliobolus sativus Jto and Kurb) and mesh (Pyrenophora teres, Drechsl) patches. It was found that at an elevated air temperature and a large amount of precipitation (2013, 2014, 2016), the development of dark brown leaf spot reached $30-40 \%$. In dry and warm weather $(2012,2015)$, the development of leaf pathogens was weak from 1 to $10 \%$. The defeat of the net leaf spot in our experiments under any suitable conditions was $5-10 \%$ weak. The resistance to the dark brown patches of the new promising lines L1505 and L1623 is significantly higher than the standards. There were no significant differences in the degree of damage to the net spotting of these varieties.
\end{abstract}

Keywords—spring barley; fastness; stability to disease; meteorological factors

\section{INTRODUCTION}

Among the crops grown by humans, barley is considered to be the fourth most important crop after maize, rice and wheat. But it has the widest range of distribution. Barley is cultivated in arid regions of the Middle East, on the Tibetan plateau at an altitude of over 4000 meters above sea level, in North and East Africa. Northern border of cultivation of barley coincides with the boundary of the cultivation of other crops. Such a wide range of cultivation of this cereal acquired due to genetic plasticity, allowing one to adapt to different conditions. In Russia, more than 100 varieties of spring barley have been zoned [6].

One of the reasons of incomplete realization of productivity potential varieties of barley is a massive defeat of crops diseases [7-9,20,25]. Diseases and pests cause significant losses to world agricultural production, they are estimated at an average of $35 \%$, including in Europe- $25 \%$, in Asia and Africa - 43-45 \% [6, 20,21]. According to FAO, crop losses account for about 30\% annually. This leads to an increase in the consumption of pesticides - every 10 years the volume of their use almost doubles [6]. Losses of barley harvest from fungal diseases are estimated at 13-17\%, and in some years reach $30 \%$ [16,22,27].

Over the past few decades, the annual cost of losses of crop production in the world due to biotic stressors has reached $\$ 25$ billion and it is all against the background of increasing scale of pesticide use. The increasing occurrence of droughts in the last decade has exacerbated concomitant mass manifestations of diseases. In connection with the above, the most radical, cost-effective and environmentally safe is the creation of new sustainable varieties. Thus, due to their use, agricultural production annually receives $30 \%$ of the profit.

There are two types of plant resistance against pathogens fungal diseases: vertical and horizontal [9-12,16,22,27]. Vertical stability considered as physiological, specific, racial as the resistance of young plants. Horizontal resistance is common, field, non-specific, stable, resistance of adult plants. The first determines the stability varieties to individual races or their complex. Using sustainable varieties in the early years reduces the manifestation of the disease. 
The creation of barley varieties resistant to diseases and pests is one of the important breeding tasks. The process of creating pathogen-resistant varieties must be continuous since absolute stability cannot be achieved. As world practice shows that the cultivation of such varieties is the cheapest and environmentally friendly way to combat pests $[2,3,5,6,18,28]$. Recently in the Leningrad region the frequency of onsets and harmfulness of leaf pathogens such as powdery mildew (Blumeria graminis/DC) of reticulate (Pyrenophora teres. Drechsl) and dark-brown (Cochliobolus sativus Jto and Kurb) blotches has considerably increased [1,13-15]. If up to the year of 2010 outbreaks of leaf diseases occurred once 3-4 years, starting from the 2011 the epiphytoticses were observed in 2011 (powdery mildew), in 2013, 2014 and 2016 (powdery mildew, dark-brown blotch $[1,2]$. Crop losses in susceptible varieties can reach $20-60 \% \quad[3,7,19,23,30]$. When plants are affected by fungal diseases, the synthesis of leaves photosynthetic pigments is hindered [26,28]. As a result, a significant crop loss, the plants stooling declines, the number of grains in a head and weight of 1000 grains reduces [13].

An important task of modern breeding is to create barley varieties resistant to fungal diseases. Breeding varieties resistant to disease is a complex problem. The genes of resistance to powdery mildew are quickly overcome by the pathogen. Oligogenic resistance to other obligate pathogens is lost more slowly. The number of donors is limited and it seems necessary to strengthen selection for horizontal longterm, though incomplete, sustainability [9,10,20,28]. World practice shows that the cultivation of such varieties is the cheapest and environmentally friendly way to fight pathogens $[4,6,9]$.

Back in the mid 70-ies of the XX century A. I. Trofimovskaia started the search for donors that resistant to the barley leaves diseases from genetic centers of origin [1]. Creation of such varieties is a difficult task, since the vast majority of pathogens has huge breeding ratio with a rapid succession of generations. So, the maximum breeding ratio of rust fungi is 1045. Many pathogens are presented by a huge number of physiological races in nature. The evolution of pathogens is rapid. Aggressive, well-adapted highly specific forms are being created [8,20-23,28].

The majority of varieties is created on basis of hybridization. It still remains a reliable and effective method $[4,6,10,13,17,31]$. Breeding for disease and parasites resistance, for the adaptability to the environmental conditions, for the specific length of the growing season provides varieties and hybrids with high stable yields. I. E. van der Plank, R.A. Robins talking about the plant-parasite complex relations, about vertical and horizontal resistance to pathogens, consider breeding work as a continuous contest with the parasite $[24,29]$.

In the Leningrad Agricultural Research Institute "Belogorka," a systematic work on developing varie-ties resistant to fungal diseases is being carried out. Another important area of breeding work of the Institute is creation of early ripening varieties of spring barley. Varieties with shorter growing season tend to have a good starter growth, they use a spring moisture well, when stocks of productive moisture in the topsoil is at the optimal level of $45-50 \mathrm{~mm}$. When ripening early they do not meet rainy conditions of August, because the maximum precipitation during the vegetation season falls in this period in the North-Western region. This slows down the ripening of grain crops, hampers the harvest. Early ripening varieties may not be exposed to diseases because their phenophases and the development cycle of a pathogen will not coincide. Unfortunately, there is a negative correlation between early ripeness and productivity: early ripening varieties are less productive than varieties with a longer growing season because they have less time to create a harvest.

The purpose of the research was to distinguish promising lines of spring barley of feed direction of productivity, early ripeness, resistance to leaf pathogens and adverse climatic conditions.

\section{MATERIALS AND METHOD}

Multi-contour land plot with an area of 1000.3 hectares, belonging to the Leningrad Scientific Research Institute of Agriculture "Belogorka" located at the address: Leningrad Region, Gatchina District. This land plot is located in the most drained northern part of the Oredezh Plateau on the Devonian sandstones that are exposed on the cliffs of the Oredezh River.

The northern part of the site is slightly undulating plain, hollow down to the south, well drained, deeply incised valley. Oredezh only in the western part is suffering from temporarily excessive moisture. The southern part of the site has a crossed moraine-erosion relief. The highest part of this territory is a large ridge, stretching from west to east, and to the north and south gradually turns into a plain. The plain to the south of the ridge lies much lower than to the north of it. In massifs dominating upland surfaces, they are almost flat, sometimes complicated by mild depressions and poorly dissected by hollow-shaped and hollow-shaped depressions, gentle hills. Soil-forming rocks are mainly moraine deposits, covering the bedrock with a cloak up to $4-6 \mathrm{~m}$ thick. Moraine is carbonate-free, but sometimes there are fragments of limestone, which almost do not affect the soil formation in conditions of normal moisture, but cause the rigidity of groundwater, are the reason for the strong saturation of the soil bases of depressions. In the southeastern part of the land, there are deposits of tuffs. Most of the soils are cultivated farms. Due to easy grading, podzolic $\mathrm{A}_{2}$ horizon and often a transitional horizon $\mathrm{A}_{2} \mathrm{~B}$ profile stand out. More than three quarters of the arable land is suitable for the cultivation of grain crops.

The soil in samples is sod-podzolic, slightly-argillaceous, of moderate cultural state.

In natural infectious background of sample fields of the Institute, the determination of resistance to leaf pathogens was held during 6 years. Percentage of pathogenic mechanism was defined in accordance with the E. E. Geshele scales [9] at the heading stage - the beginning of milky ripeness. The Suzdalets (nutans) and Leningrad (pallidum) varieties, recommended for the Northwest region, are taken as standards. Methodical Guidelines were used to characterize the varieties and lines of barley on the economically valuable characters [31]. Data of 
air temperature and precipitation were received in the local weather station of the Belogorka village.

The main method of the spring barley breeding in the Institute is intraspecific (intervarietal) hybridization using the methods of applied biotechnology with subsequent individual selection. The principle of ecological-geographical remoteness of the parental varieties is used [18].

The best released varieties of our Institute, sources and donors of valuable characters and properties from the collection of Federal Research Center All-Union Research Institute of Plant Breeding named after N. I. Vavilov are taken. The foreign selection varieties of Western European countries are actively used: Latvia, Lithuania, Germany, the Czech Republic, Sweden, Denmark, the CIS countries: Belarus, Ukraine.

Breeding work on spring barley is deployed according to the full selection process scheme $[4,18,31]$.

\section{RESULTS OF THE RESEARCH}

Table 1 presents meteorological data of spring barley growing season from May to August during six years: the average daily air temperature (t0C), the precipitation amount $\left(\sum \mathrm{H} \mathrm{mm}\right)$, the sum of effective temperatures (higher than $5^{\circ} \mathrm{C}$ ) $\left(\sum \mathrm{t}^{0} \mathrm{C}\right.$ ef.) and hydrothermic coefficient (HTC). HTC gives an opportunity to characterize the water availability more accurate than the precipitation amount, which cannot be used because the precipitation vaporizes partially. When HTC is 1.2 -2.0 - conditions are optimal for plant growth and development; if HTC > 2.0 - overwetting occurs and, as a consequence, there is lodging of plants, secondary tillering and yield reduction.

The years of 2012 and 2015 were similar in weather conditions. The air temperature was 0.7 and $0.30^{\circ} \mathrm{C}$ above normal. Water deficit amounted to 43.1 and $38.9 \mathrm{~mm}, \sum \mathrm{t}^{0} \mathrm{C}$ ef. was 22.8 and $72^{\circ} \mathrm{C}$, less than long-time average annual, HTC 2.1 and 2.2 , by years respectively. The years of 2013, 2014 and 2016 were also similar in weather data. The air temperature was 2.6 and $1.70^{\circ} \mathrm{C}$ higher than long-time average annual. The precipitation amount was $3.5 \mathrm{~mm}, 44.0 \mathrm{~mm}$ and $77.2 \mathrm{~mm}$ higher than climatic norm, $\sum \mathrm{t}^{0} \mathrm{C}$ ef. was 210.9 and $100.20 \mathrm{C}$ above norm, HTC $2.0 ; 2.5 ; 2.8$ by years respectively. The year of 2017 was very unfavorable for the vegetation of plants: the great amount of precipitation - $319.9 \mathrm{~mm}$; it is 28.1 $\mathrm{mm}$ more than the norm; low air temperature of $12.9^{\circ} \mathrm{C}, \sum \mathrm{t} 0 \mathrm{C}$ ef. amounted to $971.70 \mathrm{C}$ which is $207.3^{\circ} \mathrm{C}$ lower than norm, HTC - 3.3. Heavy over wetting and insufficient heat supply were the limiting factors of the growth and development of plants and leaf pathogens.

Table 2 presents data on dark-brown and net blotch expansion for the period from 2012 till 2017. On dry and moderately warm weather of 2012 and 2015, a weak effect of dark-brown blotch of $1-10 \%$ was observed. New prospective lines L1505 and L1623 were more resistant to this pathogen. Pathogenic mechanism was weak - 10\%. In 2013, 2014 and 2016 in warm weather conditions with a large amount of precipitation, strong development of dark-brown net of 30$40 \%$ was detected. In 2017, a strong lesion of leaves with a dark-brown blotch was noted only in the Leningrad variety $(40 \%)$ on cool $\left(\sum \mathrm{t}^{0} \mathrm{C}\right.$ ef., $207.3^{\circ} \mathrm{C}$ less than the average annual) and wet weather (HTC - 3.3). The Suzdalets variety and prospective lines had a slight lesion of 5-15\%. The weak development of foliar parasites in 2017 can be explained by low temperature and very high humidity. In recent years, modern varieties are affected by net blotch to a lesser extent $[1,2]$. Our experiments conducted from 2012 to 2017 showed that a degree of lesion by these pathogens was weak (5-10\%) in barley with hexastichous form of head (pallidum) and moderate one $15-20 \%$ ) in barley with distichous form of head (nutans).

TABLE I. METEOROLOGICAL CONDITIONS OF THE SPRING BARLEY VEGETATION SEASON FROM MAY TO AUGUST (2012-2017)

\begin{tabular}{|c|c|c|c|c|c|c|}
\hline $\begin{array}{c}\text { Weather } \\
\text { data,\# }\end{array}$ & 2012 & 2013 & 2014 & 2015 & 2016 & 2017 \\
\hline \multirow[b]{2}{*}{1} & \multicolumn{6}{|c|}{ The average daily air temperature, $t^{0} \mathrm{C}$} \\
\hline & $\frac{+14.4}{+0.7}$ & $\frac{+16.3}{+2.6}$ & $\frac{+15.4}{+1.7}$ & $\frac{+14.0}{+0.3}$ & $\frac{+15.4}{+1.7}$ & $\frac{+12.9}{-0.8}$ \\
\hline \multirow[b]{2}{*}{2} & \multicolumn{6}{|c|}{ Precipitation amount, $\mathrm{H} \mathrm{mm}$} \\
\hline & $\frac{237.9}{-43.1}$ & $\frac{284.5}{+3.5}$ & $\frac{325.0}{+44.0}$ & $\frac{242.1}{-38.9}$ & $\frac{358.2}{+77.2}$ & $\frac{319.9}{+38.1}$ \\
\hline \multirow[b]{2}{*}{3} & \multicolumn{6}{|c|}{ The effective temperature sum $\sum \mathrm{t}^{0} \mathrm{C}$ ef. $>50 \mathrm{C}$} \\
\hline & $\frac{1156.2}{-22.8}$ & $\frac{1389.9}{+210.9}$ & $\frac{1279.2}{+100.2}$ & $\frac{1107.0}{-72.0}$ & $\frac{1279.2}{+100.2}$ & $\frac{971,7}{-}$ \\
\hline \multirow{2}{*}{4} & \multicolumn{6}{|c|}{ HTC } \\
\hline & 2.1 & 2.0 & 2.5 & 2.2 & 2.8 & 3.3 \\
\hline
\end{tabular}

Perhaps this is due to the fact that there are new varieties that are more resistant to this pathogen. The calculation of the Spearman rank correlation coefficient $\left(R_{S}\right)$ revealed that the new prospective lines are reliably resistant to dark brown blotch than the standard varieties. At the 0.05 level, Rs amounted to 0.857 , critical value is $\mathrm{Rs}=0.780$. There are no significant differences in the degree of lesion of the leaves by the net blotch of spring barley, Rs was 0.464 . 
TABLE II. CHARACTERISTICS OF PROMISING HYBRIDS OF SPRING BARLEY BY RESISTANCE TO LEAF BLOTCHES (2012-2017)

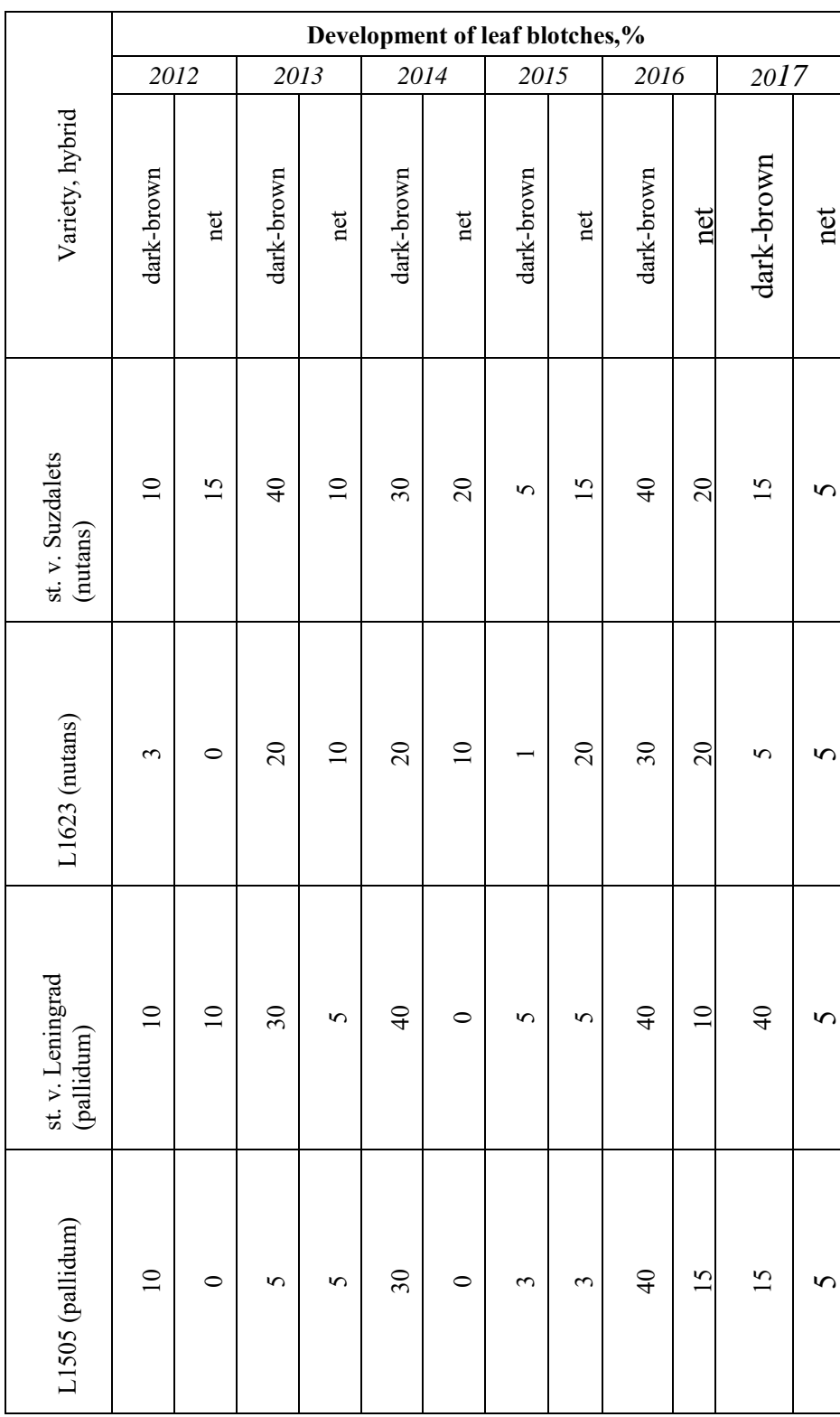

\section{CONCLUSIONS}

Studies have shown that new prospective lines L1505 and L1623 are reliably more resistant to dark-brown blotch than standard varieties Suzdalets and Leningrad. They were less affected by this pathogen in all weather conditions of 20122017. With a high humidity and an elevated air temperature during the vegetative season when the weather was warm, the development of pathogens was weak (5-10\%). The research results will help to conduct a focused selection for creating varieties with integrated resistance to leaf diseases.

\section{References}

[1] O.S. Afanasenko The role of A.Ya., "Trofimovskaya in the development of research on the immunolog-ical characteristics of barley from the genetic centers of evolution", Applied Botany, Genetics and Breeding, Vol. 165,St. Petersburg, pp.8-12, 2009.

[2] A.V. Anisimova, A.G. Semenova, "Complex stability of native and introduced barley varieties to leaf diseases and Swedish fly in the conditions of the Leningrad Region"Proceedings of Saint-Petersburg State Agrarian University, Vol. 2, pp.41-48,2017.

[3] A. Adugna, "Alternate Approaches in Deploying Genes for Disease Resistance in Crop Plants", Asian Journal of Plant Sciences, Vol.3,2004,

[4] S. Boroevich, Principles and methods of plant Moscow: Kolos,1984, pp. $160-188$

[5] M. Donatelli, R.D. Magarey, S. Bregaglio, L. Willocquet, J.P.M. Whish and S. Savary, "Modelling the impacts of pests and diseases on agricultural systems", Agricultural Systems. Jul; Vol.155, pp.213224,2017

[6] E.G. Filippov, A.V. Alabushev Breeding of spring barley. - Rostov n D: Kniga, 2014, p.208

[7] T. Gagkevaand, M. Levitin, "Composition of Fusarium graminearum schwabe populations collected from different regions of Russia". Cereal Research Communications Vol.25, No.3/2, pp. 591-594, [In Proceedings of the 5th European Seminar, Szeged, Hungary, 26 August 5 September, p. 1500, 1997]

[8] L. Gilchrist, H. Vivar, Franco, J. Crossa, "Comparing Fusarium graminearum infection period in wheat and barley". Cereal Research Communications Vol.25, No.3/2, 2000, pp. 739-740. [In Proceedings of the $5^{\text {th }}$ European Seminar, Szeged, Hungary, 26 August -5 September, p. 900,1997];

[9] E.E. Geshele Fundamentals of phytopathological evaluation in plant selection. Moscow: «Kolos»,1978, p. 208

[10] G.V Gulyaev, A.P. Dubinin. Selection and seed farming of field crops with the basics of genetics. Moscow, «Kolos», 1980, p. 180

[11] M.A. Hamdany, M.M. Salih, I.A. Al-Dulami, "Selection of mildew and smut resistant lines from barley induced mutants". [In proceedings of the $8^{\text {th }}$ congress of the Mediterranean phytopathological union. October 28 November 3rd, Agadir Morocco, pp. 279 - 280,1990]

[12] P. H. F.Hobbelen , N. D. Paveley, B. A. J. Fraaije, A. Lucas., F.Bosch "Derivation and testing of a model to predict selection for fungicide resistance", Plant Pathology, Vol. 60, pp. 304-313,2011.

[13] M.V. Ivanov, N.V. Ivanova, "Varieties of spring barley for the NorthWest of Russia", Works on applied botany, genetics and selection, Vol. 162 , pp.78-83, 2006.

[14] N.V. Ivanova, T.N. Radyukevich, A.V. Anisimova, Sources of economic-valuable signs of spring barley for creating varieties of a new generation, adapted to the conditions of the North-West region of Russia- Belogorka, 2013,16 p.

[15] O.N. Kovaleva, N.V. Ivanova "A new source material for barley breeding in the North-West of Russia" Proceedings on Applied Botany, Genetics and Selection, St. Petersburg, Vol 171, ,pp. 284-286, 2013.

[16] A.C. Kushalappa, K.N. Yogendra, S.Karre "Plant innate immune response: qualitative and quantitative resistance" Crit. Rev. Plant Sci. Vol. 35, pp.38-55,2016.

[17] Ya.Lekesh, I.Bares, A.Foral, International Classifier of the HardeumLeningrad, 1983, p. 50

[18] I.G. Loskutov Methodical guidelines for studying and preserving the world collection of barley and oats. St. Petersburg: N.I.Vavilov Research Institute of Plant Industry, 2012, p. 63

[19] J. S. Makepeace, S. J. P. Oxley., N. D. Havis, R.. Hackett, Burke J. I., J. K. M. Brown, "Associations be-tween fungal and abiotic leaf spotting and the presence of mlo alleles in barley", Plant Pathology, Vol. 56, pp.934-942, 2007. 
[20] R..Niks, U.Walther, H. Jaiser, F.Martinez, D.Rubiales, "Resistance against barley leaf rust (Puccinia hordei) in West-European spring barley germplasm", Agronomie, EDP Sciences, Vol. 20 (7), pp.769-782, 2000.

[21] M-L. Pilet-Naye, B.Moury, V.Caffier "Quantitative Resistance to Plant Pathogens in Pyramiding Strategies for Durable Crop Protection", Front Plant Sci.; Vol. 8, pp.18-38,2017.

[22] H.O. Pinnschmidt, M.S. Hovmøller, H.Østergård, “Approaches for field assessment of resistance to leaf pathogens in spring barley varieties",Plant Breeding, Vol. 125, pp.105-113,2006

[23] P.M. Politico Monitoring pests, diseases and weeds in modern technologies of cultivation of crops in plant protection. The author's abstract of the dissertation of the doctor of biological sciences. Moscow, 1997,42 p.

[24] R.A. Robinson Plant Pathosystems. Springer-Verlag, Berlin/Heidelberg/New Vork, 1976, 184 p.

[25] B.Salas, B.J Steffenson, H.H. Casper, L.K. Prom, "Fusarium species pathogenic to barley and their associated toxins", Cereal Research Communications, Vol.25, No:3/1, ,pp. 483-487, 1997.

[26] I.N. Shchennikova, E.M. Lisitsyn, L.P. Kokina, "Changes in the pigmentary complex of flag leaves of barley under the influence of edaphic stress", Agrarian Science of the Euro-Northeast, Vol.1 (16) pp.24-29,2010.
[27] K.Toyoda, N.C.Collins, A.Takahashi, K.Shiras, "Resistance and Susceptibility of Plants to Fungal Pathogens", Transgenic Research Vol. 11, Issue 6, pp 567-582,2002.

[28] L.G.Tyryshkin, N.S.Manaenko, I.A.Terentyeva, O.P. Kovaleva "Stability of collection samples of spring barley for powdery mildew" Proceedings of Applied Botany, Genetics and Selection, Vol. 165, St. Petersburg, pp.220-221,2009.

[29] Van der Plank. Genetic and Molecular Basis of Pkant Pahhogenesis. Springer - Verlag, Ber-lin/Heidelberg/New Vork, 1978, 167 p.

[30] I.O. Yudin, A.G. Semenova, "Influence of weather conditions on harmfulness of the Swedish fly", The role of young scientists in solving urgent probems of the agro-industrial complex: Collection of scientific papers of the international scientific-practical conference of young scientists. Saint-Petersburg State Agrarian University,pp.90-93,2017.

[31] Methodical guidelines for studying and preserving the world collection of barley and oats St. Petersburg: N.I.Vavilov Research Institute of Plant Industry, 2012,63 p. 